\title{
Thaumatin Isolated from Katemfe Fruit of Thaumatococcus daiellii Inhibits 3T3 L1 Adipocytes Differenciation
}

\author{
Jae-Young Cha*, Jae-Jun Jeong, Hyun-Ju Yang, Jun-Seok Park, Hyun-Woo Kim, Su-Hyun Kim and \\ Hae-Jung Jung
}

\section{Technical Research Institute, Daesun Distilling Co., Ltd, Giryoung-ri, Jangan-eup, Gijang-gun, Busan 619-951, Korea}

Received June 3, 2011 /Accepted June 10, 2011

\begin{abstract}
The effects of thaumatin isolated from katemfe fruit of Thaumatococcus daiellii Benth on 3T3-L1 preadipocyte differentiation was investigated in vitro.3T3-L1 adipocytes were treated with various concentrations of thaumatin ranging in $0-5 \mu \mathrm{M}$. Thaumatin reduced fat accumulation in differentiated 3T3-L1 adipocytes in a dose-dependent manner. 3T3-L1 cell proliferation was 97.0 and $88.3 \%$ at 1 and $3 \mu \mathrm{M}$ after 8 days of thaumatin treatment, respectively. Thaumatin showed a potent inhibitory effect on stained lipid droplets at a concentration of $3 \mu \mathrm{M}$. Thaumatin reduced triglyceride accumulation in differentiated 3T3-L1 cells in a dose-dependent manner, compared with positive control cells. This study provides basic information on the anti-obesity activity of thaumatin.
\end{abstract}

Key words : 3T3-L1 adipocyte cells, thaumatin, Thaumatococcus daiellii Benth, sweet-protein

\section{Introduction}

Lifestyle-related diseases such as diabetes, hypertension, obesity, and hyperlipidemia have raised important problems in developed countries [5,17]. These might be linked to staggering increases in the incidences of being overweight and obesity attributable to excessive intake of high-calorie foods. Therefore, low-calorie sugar substitutes can be used in beverages, foods, and medicines. Sweet-tasting proteins have a potential as low-calorie sugar substitutes [8,9]. Most proteins are tasteless and flavorless, while some proteins elicit a sweet-taste response on the human palate.

Thaumatin is the most potently sweet-tasting protein isolated from the arils of Thaumatococcus daniellii Benth, a plant native to tropical West Africa [15]. Thaumatin is a single polypeptide chain protein of 207 amino acid residues with eight disulfide bonds and the molecular mass of protein is $22 \mathrm{kDa}[6,16]$. Thaumatin is nearly 100,000 times sweeter than sucrose on a molar basis and about 1,600 times sweeter on a weight basis [6]. Thaumatin elicits a sweet taste in humans at about $50 \mathrm{nM}$, the lowest concentration for any sweet-tasting protein [12]. Thaumatin, a nontoxic protein, has been approved for use in many countries as a flavor enhancement, taste masking, intense

\footnotetext{
*Corresponding author

Tel : +82-51-730-9201, Fax : +82-51-730-9188

E-mail : e996390@yahoo.co.kr
}

sweetness, and synergistic properties to produce dramatic effects in food products [3].

Stevioside isolated from Stevia rebaudian Bertoni, which has been known one of sweets, showed the antiobesity effect on the high fat diet-induced obese mice [13]. However, the effect of thaumatin on the differentiation to adipocytes has not been reported. This study was to determine the effect of thaumatin on adipocyte differentiation in 3T3-L1 mouse fibroblasts.

\section{Materials and Methods}

\section{Thaumatin HPLC analysis}

Purified thaumatin powder was obtained from Naturex LTD. (London, U.K.). The thaumatin was analyzed by Agilent 1200 HPLC system (Agilent Technologies, Santa Clara, CA, U.S.A.) using a reversed-phase Zorbax Eclipse XDB-C18 column $(5 \mu \mathrm{m}, 4.6 \mathrm{~mm} \times 150 \mathrm{~mm})$ using a gradient solvent system at a flow rate of $1.0 \mathrm{ml} / \mathrm{min}$. Solvents were acetonitrile added $0.1 \%$ trifluoroacetate and water added $0.1 \%$ trifluoroacetate. The column temperature was $30^{\circ} \mathrm{C}$. Thaumatin was detected by DAD (diode array detector) at $280 \mathrm{~nm}$ and ELSD (evaporative light scattering detection). The evaporator temperature for ELSD was set at $60^{\circ} \mathrm{C}$, nebulizing gas (N2) pressure was 3.5 bar.

\author{
Cell culture \\ 3T3-L1 preadipocytes were obtained from the American
}


Type Culture Collection (Manassas, VA, U.S.A.) and were cultured in Dulbecco's modified Eagle's medium (DMEM) (Sigma-Aldrich, St. Louis, MO, U.S.A.) containing $10 \%$ bovine calf serum (BCS) until confluence. All media contained pen-strep. The differentiation of preadipocytes was carried out in DMEM supplemented with 10\% fetal bovine serum (FBS), $0.5 \mathrm{mM}$ 3-isobutyl-1-methylxanthineIBMX (Sigma-Aldrich), $0.25 \mu \mathrm{M}$ dexamethasone (SigmaAldrich), and $5 \mathrm{\mu g} / \mathrm{ml}$ insulin for another 2 days. Cells were treated with insulin for another 2 days and maintained in DMEM supplemented with 10\% FBS for additional 4 days (8 days) [14].

\section{Cytotoxicity assay}

Growth inhibitory activity of thaumatin on 3T3-L1 preadipocytes was determined by 3-(4,5-dimethylthiazol-2yl)-2,5-diphenyltetrazolium bromide (MTT) assay [11]. Thaumatin was dissolved in water at concentrations $5 \mu \mathrm{M}$ and filtered using a $0.2 \mu \mathrm{m}$ syringe filter (Sartorius, Germany). Before treatment, cells were first grown overnight on a 96 well plate at a density of $5 \times 10^{4}$ cells/well, and then various concentrations of thaumatin were added into the 96 well plate and cells were incubated for an additional $48 \mathrm{hr}$ at $37^{\circ} \mathrm{C}$. After $48 \mathrm{hr}$ of incubation, $12 \mathrm{mM}$ MTT was added and further incubated for $4 \mathrm{hr}$ at $37^{\circ} \mathrm{C}$. The MTT solution was remove all but $25 \mathrm{ul}$ of medium from the wells, and the resulting formazan product, which was converted by viable cells, was dissolved in $50 \mu 1$ dimethylsulfoxide. The absorbance was read by an enzyme-linked immunosorbent assay (ELISA) plate reader at $540 \mathrm{~nm}$ with a $620 \mathrm{~nm}$ reference. Cell viability is expressed as a percentage of the absorbance seen in untreated control cells.

\section{Oil-Red O staining}

Intercellular lipid accumulation was measured using Oil-Red-O staining method [14]. 3T3-L1 adipocytes were treated with thaumatin for whole differentiation process (days 0-8). On 8 days, differentiated 3T3-L1 preadipocytes were washed twice with cold distilled water and fixed in $10 \%$ formalin at room temperature for $1 \mathrm{hr}$ and then wash with $60 \%$ isopropanol, stained with $3 \mathrm{mg} / \mathrm{ml}$ Oil-Red-O (Sigma-Aldrich) (in 60\% isopropanol) for $1 \mathrm{hr}$ after washing with distilled water. 3T3-L1 preadipocytes were eluted with $100 \%$ isopropanol and then observed under a microscope (Olympus, Japan). The absorbance (O.D. $510 \mathrm{~nm}$ ) was measured by a spectrophotometer (VERSAmax, USA).

\section{Determination of cellular triglyceide concentration}

The cellular protein concentration was determined using BCA protein assay reagent (Pierce, Rockford, IL, USA). Total lipids in the cells were extracted and purified using the method of Bligh and Dyer [1]. The triglyceride content was determined enzymatically using commercial kits [10].

\section{Statistical analyses}

The data are presented as the mean $\pm \mathrm{SD}$, and were analyzed using one way analysis of variance (ANOVA), with the differences analyzed using the Duncan's new multiple-range test [2]. A $p$ value $<0.05$ was accepted as being a statistical significance of difference.

\section{Results and Discussion}

\section{Thaumatin analysis}

Thaumatin is an intensely sweet protein isolated from the katemfe fruit of the West Africa tropical plant $T$. daniellii Benth. This protein is approximately 100,000 times sweeter than sucrose on a molar basis and about 1,600 times sweeter on a weight basis [6], followed by thaumatin which is 3,000 times sweeter than sucrose. Thaumatin was observed with an HPLC retention time of $10.7 \mathrm{~min}$ and peak shape was sharp (Fig. 1).

\section{Cell proliferation}

The 3T3-L1 cell line is one of the most well-characterized and reliable models for studying the conversion of preadiposites into adipocytes. Adiposite is primary site for energy storage and accumulates triglyceride during nutritional excess [7]. Adipogenesis of 3T3-L1 preadipocyte is often used in anti-obesity treatment. Adipocyte differentiation was induced in 3T3-L1 preadipocytes by treatment with the mixture of dexamethasone, 3-iso-butyl-1-methylxanthine, and insulin [4]. 3T3-L1 preadipocyte cells were treated with 0 ,

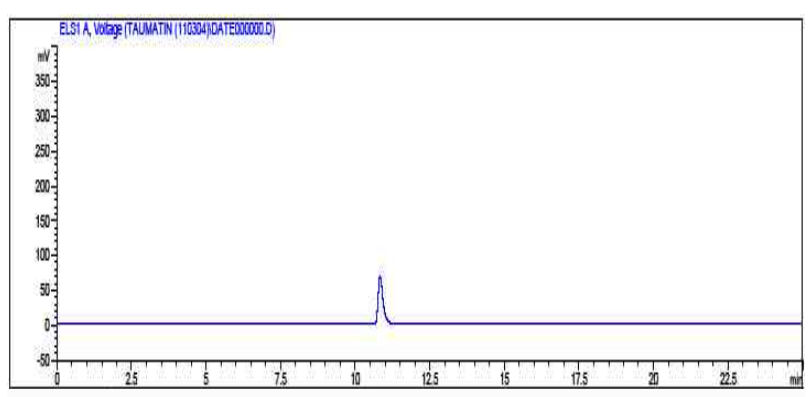

Fig. 1. HPLC chromatogram of thaumatin at $0.1 \%(w / v)$ 
1,3 , and $5 \mu \mathrm{M}$ thaumatin and the cell proliferation was measured by the MTT assay. As shown in Fig. 2, cell proliferation was 97.0 and $88.3 \%$ at 1 and $3 \mu \mathrm{M}$ for 8 days of thaumatin treatment and significant inhibition was found at concentration $>5 \mu \mathrm{M}$. Therefore, 1-3 $\mu \mathrm{M}$ concentrations of thaumatin were used for further experiments.

Fat accumulation in differentiated 3T3-L1 adipocytes

3T3-L1 preadipocyte cells were treated with 1 and $3 \mu \mathrm{M}$ of thaumatin and the accumulated lipid droplets were visualized by Oil-Red-O staining at days 8. Quantification of Oil-Red-O in the cells confirmed that thaumatin showed potent inhibitory activity on stained lipid droplets at a concentration of $3 \mu \mathrm{M}$ (Fig. 3 and 4). The obtained result showed that thaumatin may possess a key role in responsible for decreasing the obesity development by body fat accumulation.

To further identify the adipogenic effects of thaumatin, the amounts of accumulated triglyceride were verified in positive control cells on day 8 , but thaumatin reduced triglyceride accumulation in differentiated 3T3-L1 cells in a dose-dependent manner, compared with positive control cells (Fig. 5). These results suggest that thaumatin strongly reduces the differentiation of 3T3-L1 preadipocyte cells. Park et al. reported that stevioside isolated from $S$. rebaudian

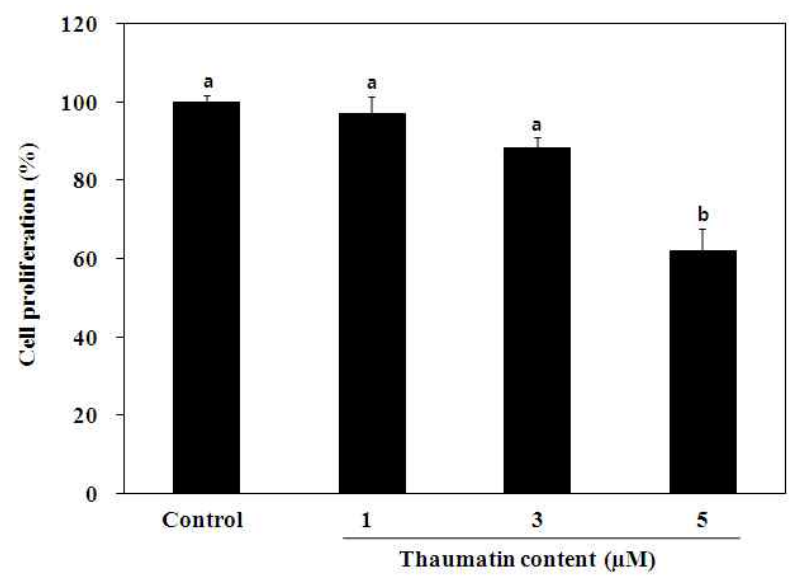

Fig. 2. Effect of thaumatin on cell proliferation in 3T3-L1 adipocyte cells. Differentiation was induced with DMI (M; 0.5 $\mathrm{mM}$ 3-isobutyl-1-methylxanthine, $\mathrm{D} ; 0.25 \mu \mathrm{M}$ dexamethasone, I; $10 \mu \mathrm{g} / \mathrm{ml}$ insulin) for 8 days. Results are expressed as mean \pm S.D. of three independent experiments, each performed using triplicate wells. Sample untreated cells were used as negative control.

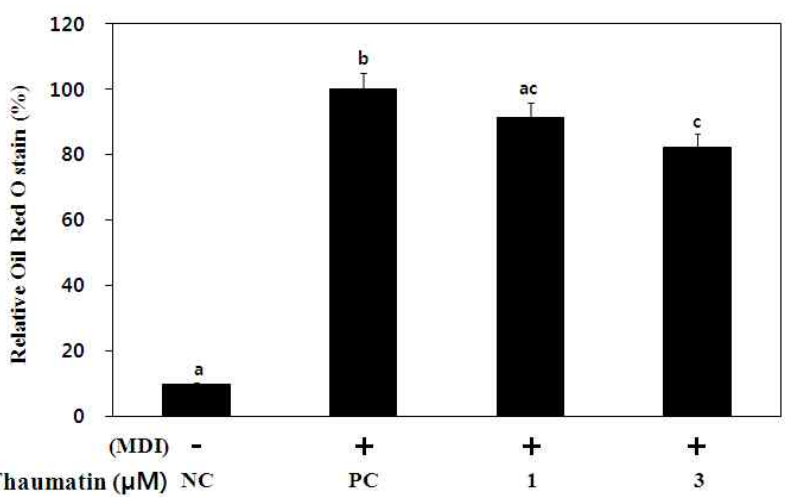

Fig. 3. Effect of thaumatin on stained lipid droplets in 3T3-L1 adipocyte cells. Differentiation was induced with DMI (M; $0.5 \mathrm{mM}$ 3-isobutyl-1-methylxanthine, D; $0.25 \mu \mathrm{M}$ dexamethasone, I; $10 \mathrm{\mu g} / \mathrm{ml}$ insulin). Untreated cells were used as negative control. NC; negative control, PC; positive control. Cells were treated with thaumatin for whole differentiation process (days $0-8$ ). On day 8 , cells were stained with Oil-red-O.

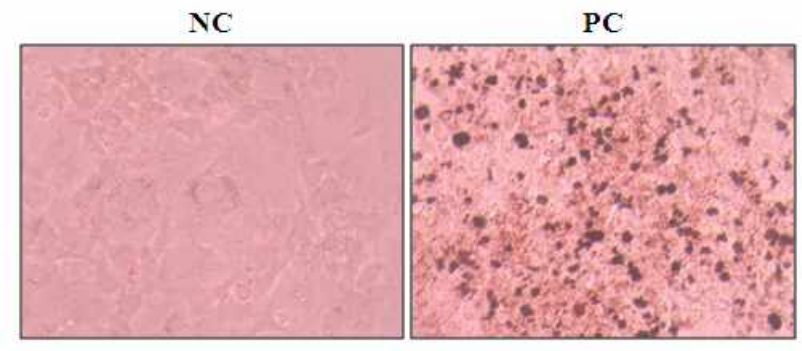

1 3

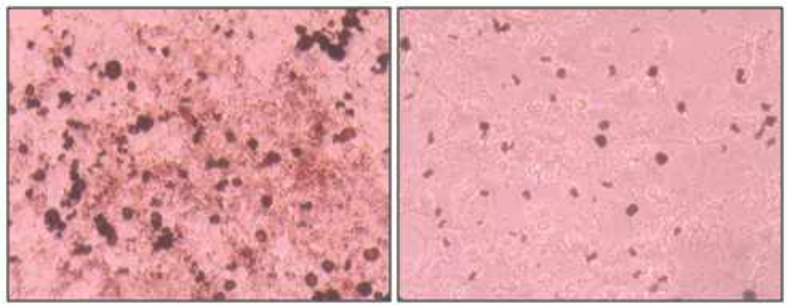

Fig. 4. Effect of thaumatin on Oil-red-O stained lipid droplets in 3T3-L1 adipocyte cells. Differentiation was induced with DMI (M; $0.5 \mathrm{mM}$ 3-isobutyl-1-methylxanthine, D; $0.25 \mu \mathrm{M}$ dexamethasone, I; $10 \mu \mathrm{g} / \mathrm{ml}$ insulin). Untreated cells were used as negative control. NC; negative control, PC; positive control, $1 ; 1 \mu \mathrm{M}$ thaumatin, $3 ; 3 \mu \mathrm{M}$ thaumatin.

Bertoni was also significantly decreased the epididymal fat weight in C57BL/6J mice fed high fat diet [13]. Accordingly, thaumatin could play important roles in regulating lipid metabolism in obesity treatment. This study provides basic information on anti-obesity activity of thaumatin. 


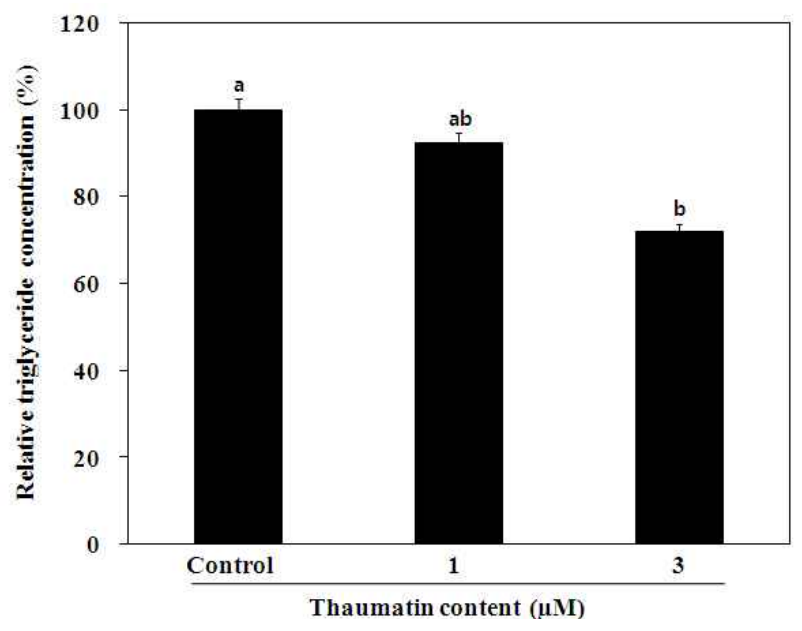

Fig. 5. Effect of thuamatin on triglyceide concentrations in 3T3-L1 adipocyte cells. Differentiation was induced with DMI (M; 0.5 mM 3-isobutyl-1-methylxanthine, D; 0.25 $\mu \mathrm{M}$ dexamethasone, I; $10 \mu \mathrm{g} / \mathrm{ml}$ insulin). Sample untreated cells were used as control.

\section{References}

1. Bligh, E. G. and W. J. Dyer. 1959. A rapid method of total lipid extraction and purification. Can. J. Biochem Physiol. 37, 911-917.

2. Duncan, D. B. 1957. Multiple range test for correlated and heteroscedastic means. Biometrics 13, 164-176.

3. Etheridge, K. 1994. The sales and marketing of talin. pp. 47-59, In Witty, M. and J. D. Higginbotham (eds.), Thaumatin, CRC Press, Boca Raton.

4. Gregoire, F. M., C. M. Smas, and H. S. Sul. 1998. Understanding adipocyte differentiation. Physiol. Rev. 78, 783-809.

5. Hartz, A. J., D. C. Jr. Rupley, R. D. Kalkhoff, and A. A. Rimm. 1983. Relationship of obesity to diabetes: influence of obesity level and body fat distribution. Prev. Med 12, 351-357.

6. Iyengar, R. B., P. Smith, F. van der Ouderaa, H. van der Wel, J. van Brouwershaven, P. Ravestein, G. Richters, and
P. D. van Wassenaar. 1979. The complete amino-acid sequence of the sweet protein thaumatin I. Eur. J. Biochem 96, 193-204.

7. Jeon, G. N., Y. M. Choi, S. M. Lee, Y. H. Kim, H. H. Jeong, and J. S. Lee. 2010. Anti-obesity activity of methanol extract from hot pepper (Capsicum annuum L.) seeds in 3T3-L1 adipocyte. Food Sci. Biotechnol. 19, 1123-1127.

8. Kant, R. 2005. Sweet proteins-potential replacement for artificial low calorie sweeteners. Nutr. J. 4:5, 1-6.

9. Masuda, T. and N. Kitabatake. 2006. Developments in biotechnological production of sweet proteins. J. Biosci. Bioeng. 102, 375-389.

10. McGrowan, M. W., J. D. Artiss, D. R. Strandbergh, and B. Zak. 1983. A peroxidase-coupled method for the colorimetric determination of serum triglycerides. Clin. Chem 29, 538-542.

11. Mosmann, T. 1983. Rapid colorimetric assay for cellular growth and survival: application to proliferation and cytotoxicity assays. J. Immunol. Methods 65, 55-63.

12. Ohta, K., T. Masuda, F. Tani, and N. Kitabatake. 2011. The cysteine-rich domain of human T1R3 is necessary for the interaction between human T1R2-T1R3 sweet receptors and a sweet-tasting protein, thaumatin. Biochem Biophys. Res. Commun 406, 435-438.

13. Park, J. E., H. J. Kee, and Y. S. Cha. 2010. Effect of Stevia rebaudiana Bertoni leaf extract on antiobesisty in C57BL/6J mice. Korean J. Food Sci. Technol. 42, 586-592.

14. Shin, E. J., K. M. Choi, H. S. Yoo, C. K. Lee, and B. Y. Hwang. 2010. Inhibitory effects of coumarins from the stem barks of Fraxinus rhynchophylla on adipocyte differentiation in 3T3-L1 cells. Biol. Pharm Bull. 33, 1610-1614.

15. van der Wel, H. and K. Loeve. 1972. Isolation and characterization of thaumatin I and II, the sweet-tasting proteins from Thaumatococcus daniellii Benth. Eur. J. Biochem 31, 221-225.

16. van der Wel, H., R. B. Iyengar, J. van Brouwershaven, P. D. van Wassenaar, W. J. Bel, and F. J. van der Ouderaa. 1984. Assignment of the disulphide bonds in the sweet-tasting protein thaumatin I. Eur. J. Biochem 144, 41-45.

17. William, B. K., B. D. Ralph, and L. C. Janet. 1996. Effect of weight on cardiovascular disease. Am J. Clin. Nutr. 63, 419S-422S. 
초록 : Thaumatococcus daiellii 열매 유래 토마틴의 3T3-L1 지방전구세포 분화 억제에 의한 항비 만 효과

차재영* · 정재준 · 양현주 · 박준석 · 김현우 · 김수현 · 정해정

(대선주조(주) 기술연구소)

3T3-L1 지방전구세포 분화 억제에 대한 Thaumatococcus daiellii 열매 유래 토마틴의 항비만 효과를 검토하였다. 3T3-L1 지방전구세포에 토마틴을 0-5 $\mu \mathrm{M}$ 농도로 처리한 결과 세포생존율은 처리 농도 의존적으로 감소하였는데, 토마틴 8 일 처리 후 1 및 $3 \mu \mathrm{M}$ 농도에서 각각 $97 \%$ 및 $88.3 \%$ 의 세포생존율을 보였다. 또한 토마틴 $3 \mu \mathrm{M}$ 처리 농도에서 Oil-Red-O염색 지방구가 현저히 감소된 것으로 나타났다. 3T3-L1 세포 내 중성지방 농도는 양성 대조군 에 비해 농도 의존적으로 감소하였다. 따라서 천연 식물성 토마틴은 3T3-L1 지방전구세포의 세포증식 억제 및 중성지방 농도 감소 효과를 보여 항비만 효과가 있는 것으로 밝혀졌다. 